\title{
Turnout in European Parliament Elections: Towards a European-Centred Model
}

\author{
Richard S. Flickinger \\ Department of Political Science \\ Box 720, Wittenberg University \\ Springfield, OH 45501-0720 \\ rflickinger@wittenberg.edu \\ Donley T. Studlar \\ Eberly Distinguished Professor \\ Department of Political Science \\ West Virginia University \\ P.O. Box 6317 \\ Morgantown, WV 26506-6317 \\ dstudlar@wvu.edu \\ Stephen E. Bennett \\ Research Professor of Political Communication \\ Appalachian State University \\ 161 Chipmunk Lane \\ Blowing Rock, NC 28605 \\ sbennett@apptechnc.net
}

\section{National Europe Centre Paper No. 105}

Paper presented by Dr. Studlar at National Europe Center,

Australian National University, Canberra, 8 August 2003.

To appear in Roger Scully et al., eds. British Parties and Elections Yearbook,

Volume 13 (Frank Cass, 2003). 


\title{
Turnout in European Parliament Elections: Towards a European-Centred Model
}

\author{
Abstract: With the 2004 European Parliament elections approaching, it is useful to consider \\ what affects voting in these elections. This paper addresses the puzzle of declining turnout in \\ European Parliament elections. After reviewing the influential "second order elections" \\ explanation emphasizing domestic influences on turnout, especially Mark Franklin's recent study \\ stressing the importance of electoral salience factors, we develop a revised model to incorporate \\ EU as well as domestic variables. Our model indicates that EU influences, at least on the \\ aggregate level, may have more influence on EP elections than previously reported. Tests of our \\ model for the first five EP elections, 1979 through 1999, find that it provides an alternative \\ explanation of turnout similar in power to Franklin's model. Because of changes in membership \\ of the EU, our alternative model may be preferable for explaining future turnout variation in EU \\ elections.
}


Turnout in European Parliament Elections: Towards a European-Centred Model

\section{Introduction: The Turnout Puzzle in European Parliament Elections}

First addressed by Flickinger and Studlar (1992), it is now widely recognized that overall turnout in European Parliament (EP) elections has fallen steadily since direct elections began in 1979, reaching its nadir in the fifth election in 1999. Table 1 shows the figures, by country, for each of the five elections since 1979. Declining turnout in EP elections has concerned policymakers as well as scholars since turnout is widely considered a major indicator of institutional legitimacy in democracies (Powell, 1982; Delwit, 2002).

Turnout in EP elections matters for several other reasons as well. It indicates the public's perception of the relevance of the institution, the standing of national governments and political parties, and may help to shape the future of parties' EU policies (Butler and Westlake, 2000). Who votes also matters for who is elected, who holds power in the EP, and the attendant policy consequences (Lord, 2002). 
TABLE 1

TURNOUT IN EUROPEAN PARLIAMENT ELECTIONS

\begin{tabular}{|c|c|c|c|c|c|c|}
\hline Country & 1979 & 1984 & 1989 & 1994 & 1999 & Mean Turnout \\
\hline Belgium & 91.4 & 92.2 & 90.7 & 90.7 & 91.0 & 91.2 \\
\hline Denmark & 47.8 & 52.2 & 47.4 & 52.9 & 50.4 & 50.1 \\
\hline France & 60.7 & 56.7 & 48.8 & 52.7 & 46.8 & 53.1 \\
\hline Germany & 65.7 & 56.8 & 62.3 & 60.0 & 45.2 & 58.0 \\
\hline Britain & 32.2 & 31.8 & 36.6 & 36.4 & 24.0 & 32.2 \\
\hline Greece & $78.6^{*}$ & 77.2 & 80.1 & 80.4 & 75.3 & 78.3 \\
\hline Ireland & 63.6 & 47.6 & 68.3 & 44.0 & 50.7 & 54.8 \\
\hline Italy & 84.9 & 83.4 & 81.4 & 74.8 & 70.8 & 79.1 \\
\hline Luxembourg & 88.9 & 87.0 & 96.2 & 88.5 & 85.8 & 89.3 \\
\hline Netherlands & 58.1 & 50.6 & 47.5 & 35.6 & 29.9 & 44.3 \\
\hline Portugal & & $72.4 * *$ & 51.2 & 35.5 & 40.4 & 49.9 \\
\hline Spain & & $68.9^{* *}$ & 54.7 & 59.1 & 64.4 & 61.8 \\
\hline Austria & & & & $67.7 * * *$ & 49.0 & 58.4 \\
\hline Finland & & & & $57.6^{* * *}$ & 30.1 & 43.9 \\
\hline Sweden & & & & $41.6^{* * *}$ & 38.8 & 40.2 \\
\hline Year Mean & 67.2 & 64.7 & 63.8 & 55.1 & 49.9 & 59.0 \\
\hline
\end{tabular}

Sources: Smith (1999) and European Parliament web site, http://www2.europarl.eu.int/election/newep/en/tctp.htm (1999).

*The first Greek election occurred in 1981.

**The first elections in Portugal and Spain occurred in 1987

***The first elections in Austria and Finland occurred in 1995, in Sweden in 1996.

Starred results are included with the ones for the respective preceding general EP election. 
The lowest-ever 1999 turnout occurred despite a well-documented increase in the EP's power in EU affairs through the co-decision procedures of the Single Market Treaty of 1986, specific provisions in the Amsterdam Treaty of 1997, the conflict with the European Commission that led to the Commissioners' en masse resignation in 1998, and the EP's role in the introduction of the euro and European Central Bank (Perrineau et al., 2002; Hix, 2002). In principle, these developments, especially those occurring since 1994, should have made the 1999 EU elections more salient to the public and, ceteris paribus, generated higher turnout.

Many studies of turnout in EP elections have stressed individual characteristics such as socioeconomic traits (class, education, gender, age, income), attitudes (general political interest, party identification, sense of civic responsibility), and political behaviour (organizational membership, discussion of politics). Others have considered institutional factors (electoral systems, patterns of party competition, forms of government, election cycles).

Individual and institutional approaches to explaining turnout are especially important in the conventional explanation of European elections as 'second order', that is, the results are basically derivative of recent national elections and current party standings domestically rather than being based on issues and attitudes relating to the EU per se. Because EP elections do not determine who forms the executive in the EU, the perceived salience of the election is low, and citizens who stay away from the polls may be acting rationally. Because the elections are not perceived as important for European Union policies, their outcome depends primarily on national level partisan concerns, similar to many lower-level elections in these countries.

Surveying two EP elections (1989 and 1994), van der Eijk and Franklin (1996) argue that among the institutional effects are compulsory voting, Sunday voting, proportionality of the party system, and the timing of EP elections within the national election cycle. General political interest is the most important individual level determinant, and political orientation and an appealing party are more important than socio-demographic variables. Overall, the growing body of work on participation in EU elections continues to affirm second-order explanations, directing attention to national level variables rather than European ones (Reif and Schmitt, 1980; 
Reif, 1997; van der Eijk and Franklin, 1996; Marsh, 1998; Heath et al., 1999).

Despite acceptance of the second order thesis by many analysts of EU voting, its tenets can be questioned (Perrineau et al., 2002; Curtice and Steed, 2000). The second order explanation usually has been a static, general one, which does less well in explaining variations over time and space. Why has turnout continued to decline even as the EU, and especially the EP, become more significant political actors? Why does turnout vary so much from one country to another?

\section{Explaining Turnout Decline: Franklin's Model}

In a series of articles (especially Franklin 2001b), Mark Franklin has addressed some of the problems in the second-order explanation, especially that of continued turnout decline. This is a product of his more general comparative approach to turnout, which links individual and institutional approaches to create 'instrumental' explanations (Franklin 1996, 2002). He argues that resource (individual) characteristics and mobilization (party) factors, when combined with other contextual variables, especially the attributes of specific elections, provide the best explanations of voting turnout across countries. 'Turnout varies much more from country to country than it does between individuals' (Franklin, 1996: 218; see also Franklin, 1999; van der Eijk and Franklin, 1996; Anderson, 1998; cf. Blondel et al., 1998).

In applying this model to EP elections, Franklin (2001b) emphasises two particular structural factors which have led to turnout decline over time. The first is the declining share of EU members with compulsory voting, from three of nine countries (Belgium, Luxembourg, Italy) in 1979 to three of fifteen in 1999 (Greece was added as a compulsory in 1984, but Italy formally abandoned the practice in 1993).

Second, Franklin (2001b) finds that turnout tends to be relatively high in a country's first EP election, but is followed by a substantial drop at the next one. Turnout in the second election then becomes the pattern for subsequent ones. At the first EU elections in 1979, all countries choosing EP members were subject to this first-time boost in turnout. But in 1999, with a reduced share of compulsory voting countries and no member experiencing its first election, there were structural reasons for expecting a low turnout, absent other factors which might raise 
the salience of the election.

Following other second-order analyses, Franklin (2001b) also employs an electoral cycle measure to try to capture the salience of an EP election, based on national politics. He argues that the closer an EP election occurs before an expected national election, the more salient it becomes for national politics; consequently the EP election then arouses greater interest among the electorate. Electoral interest may also be boosted in these circumstances by the fact that parties have greater incentives to campaign and mobilize their voters than they do when an EP election is further removed in time from the next national election. Thus, turnout may be expected to be higher when the national election cycle is shorter.

Franklin's (2001b) three-variable model for the aggregate of all five EP elections is parsimonious and robust in explaining why overall turnout in EP elections continues to decline.. The regression equation accounts for more than 80 percent of the variation in turnout in EP elections among EU member states over these elections. An analysis of the estimated impact of change in each of the three predictors enables Franklin accurately to account for the difference in turnout between the 1979 election and that of 1999 (2001b: 317-18). Because of the low number of cases (only 2-5 elections in each country) Franklin cannot apply his model systematically to turnout variation in individual countries except by an analysis of residuals. Nevertheless, even this helps account for the wide variation in turnout among EU member countries in any given election.

\section{Developing an Alternative Model of European Election Turnout}

Franklin provides an impressive addition to the second-order explanation. Yet, as even he acknowledges, it is not the final word:

'We have admittedly made no attempt to apportion responsibility for turnout decline as between the variables investigated in this study and other potential effects on turnout, so there is still the possibility that other influences may have played a part, attenuating the effects we measure in this paper' (Franklin, 2001b: 321).

There are several problems with Franklin's model which suggest scope for developing an 
alternative model. First, as he recognises, his model does better retrospectively rather than prospectively in explaining turnout in EP elections. The declining share of countries with compulsory voting reduces the model's power over time. None of the ten first-wave candidates for EU membership features compulsory voting. Second, it is unclear whether the first EP election boost will occur among the new members. The new democracies of Central and Eastern Europe have had falling turnout in national elections after initially high levels (Institute for Democracy and Electoral Assistance, 2002). Whether the first EP election will have the same effect there that it did among current EU members remains an open question.

Third, as Table 1 attests, turnout after the first EP election has varied considerably among countries without compulsory voting. The election cycle variable alone cannot adequately account for this. Excluding compulsory voting countries and using only the first election and election cycle variables results in a substantial reduction in turnout variance explained for the five EP elections taken together. The adjusted $\mathrm{R}^{2}$ for this two-variable model falls to .19, compared to .80 for the three-variable one. ${ }^{1}$

It is also doubtful whether the election cycle variable alone is the best way to measure the salience of EP elections. It is a good measure if we assume that national political considerations are what matters in EP elections, as the second-order explanation claims. But can we assume that any longer? For example, Schmitt and Thomassen (2002) recently found that attitudes toward Europe have emerged as a new dimension in the electoral politics of West European countries, which cuts across the traditional left-right cleavage. Studies of recent elections, both national and EP, in one of the most "eurosceptical" of countries, the United Kingdom, have suggested that the Europe Union may be a developing cleavage (Evans, 1999; Curtice and Steed, 2000). Where and how should we look for indications that EP elections are also about European matters?

Scholars have looked for connections between attitudes toward the EU and turnout in EP elections, but these have been elusive (Schmitt and Mannheimer, 1991; see also Gabel, 2000). One study of the 1999 election finds a positive relationship between European identity and turnout, but it does not consider that several of the countries with high levels of European 
identity also have compulsory voting (Frognier, 2002). Eurobarometer 52 (2002) data indicate that opinions such as whether the country's membership is a good or bad thing, or whether one's country has benefitted from membership, are not statistically related to turnout (data not shown). According to another recent study "the evidence on the cognitive aspect of the orientations of citizens to the European Union confirms the view that well-structured, well-informed, and supportive attitudes commensurate with the current stage of integration have not in fact developed" (Cautrès and Sinnott, 2002: 12). Abram de Swaan (2002: 11) suggests this is due to the absence of a "European public space," with the result that "in every member state opinions take shape within a national framework"-yet another version of the "second order elections" argument.

But there are alternative measures of the salience of EU effects on member countries, measured at the aggregate level, which may affect turnout. We are particularly interested in economic indicators that tap the areas where EU policies are most developed: agriculture, trade, aid to economically underdeveloped areas within the organisation, and monetary union. We have identified a series of indicators of these effects, e.g., agricultural workers as a percentage of a country's total work force, trade as a percentage of GNP, status of net contributor to or net beneficiary of the EU budget, and adoption of the euro (see Appendix for details). Our expectations are that those countries with a higher percentage of agricultural workers and GNP in trade will have higher turnout, as will countries which are net budget beneficiaries and subscribers to the EMU. ${ }^{2}$

The EU's share of Europe's total GDP, though still modest, has increased during the twenty years since the first EP election in 1979 (Begg and Grimwade, 1998). From a rational expectations perspective, one would anticipate that where there is a substantial economic impact, voters may conclude that more is at stake in elections and therefore be more likely to vote. Thus, where the EU's overall impact is large (or perceived to be important from a national perspective), turnout in EP elections should be higher than in countries where these conditions are not present. $^{3}$

Since the major achievements of the EU are in trade policy, citizens in trade-dependent 
economies may have greater reason for paying attention to EU matters. A similar logic applies to citizens in countries that are major beneficiaries of the EU budget. Agriculture has been the most expensive area of EU policy, accounting for over 40 percent of total expenditure.

Controversy over reforming the Common Agricultural Policy is a perennial problem and even has threatened the enlargement process. Thus having more people engaged in agriculture may increase turnout.

Several political factors may also affect turnout: length of membership in the EU, being an original member of the EU, hosting a major EU institution, party competition in European Parliament elections, and European identity within the population. Long-term membership of the EU, along with hosting a major EU institution, creates the possibility of greater EU awareness. We also distinguish the original six members of the EU because there may be special concerns associated with being one of the founding members that do not apply to later members and are not completely captured solely by a "years of membership" variable.

Major EU institutions and their host countries are the Commission (Belgium), Parliament (France, Belgium), Court of Justice (Luxembourg), and Central Bank (Germany). We also examine a retrospective indicator of party competition, namely the number of political parties per country that won seats in the current EP election. When more parties win seats, the opportunity for meaningful voter choice is likely to encourage turnout (Crepaz, 1990). More parties act to mobilize voters, and some of the "minor" parties may stress European issues which large national parties avoid. ${ }^{4}$ Finally, the general sense of European identity within a population should increase participation in EU elections.

We do, however, retain, in a slightly revised form, Franklin's variable on the electoral cycle, by including the amount of time between the European Parliament election and the next national election. The shorter the time between the EP election and the next national election, the greater the incentives for parties to mobilize their supporters, which should lead to higher turnout.

We believe these measures of EU impact provide an opportunity to explain variations among countries and over time, which can serve as a forward-looking complement to Franklin's 
(2001b) model. We seek a model that works for countries where neither compulsory voting nor the first election phenomenon is present. 
TABLE 2

CORRELATIONS OF OBJECTIVE CONDITIONS AND ATTITUDES TOWARD THE EU IN THE 1990s ${ }^{\mathrm{a}}$

Host Orig 6 Trade AgWork EuroMem EuroID EUGood

EU Host

Original $6 \quad .676^{* *}$

GDP Trade $\quad .435^{*} \quad .289$

AgWorker $\quad-.418^{*} \quad-.434 * \quad-.319$

$\begin{array}{lllll}\text { Euro Member } \quad .364 & .492 & .323 & -.077\end{array}$

European ID $\quad .452 * \quad .660 * * \quad .274 \quad-.065 \quad .631 *$

$\begin{array}{lllllll}\text { EU Good } & .087 & .387 * & .485 * * & .256 & .436 & .472 *\end{array}$

$\begin{array}{llllllll}\text { EU Benefits } & -.023 & .070 & .436 * & .420 * & .241 & .173 & .874 * *\end{array}$

a Data are for 1994 and 1999. N =30 except for European ID (27) and Euro Member (15).

Euro membership applied only in 1999 and there were no data on European ID for the three newest members in 1994.

*significant at .05 level;

**significant at .01 level 
Our data offer some support for this line of reasoning. Although many Europeans may not have well-formed positions about the EU, they do seem to be aware of its impact. This is suggested by the existence of a number of statistically significant correlations between objective conditions and attitudes in the 1990s. See Table 2. Living in a net beneficiary country (in terms of the EU budget) is associated positively with the perception that EU membership benefits one's country. People in countries with higher proportions of agricultural workers are also more likely to see benefits from membership. Citizens of countries hosting a EU institution, being one of the "original six" members, or having adopted the euro are more likely to report they identify with Europe than do inhabitants of other countries. Finally, having a higher portion of GDP in international trade is positively correlated with seeing EU membership as good and benefitting one's country. Thus we see some connection between our indicators of salience and aggregatelevel national attitudes. ${ }^{5}$

\section{Comparing Models: Explaining Overall Turnout}

We created a series of regression equations to test for the hypothesized effects of our indicators on EU turnout by adding them to Franklin's model for all five EP elections combined. None of our economic variables added to his model's power, nor did hosting a EU institution. However, two non-economic variables did contribute: being one of the "original six" member states (.013 increase in $\mathrm{R}^{2}$ ) and hosting an EU institution (.017).

One difficulty with Franklin's model is the very large proportion of explained variance accounted for by compulsory voting (adjusted $\mathrm{R}^{2}$ of .66 in simple regression for all five elections). As noted previously, the performance of his model declines dramatically when this variable is excluded. Although compulsory voting countries account for a declining share of EU members, the influence of this variable remains dominant because of a widening gap between turnout in compulsory and non-compulsory countries. However, the dominance of this variable may mask the influence of others, especially in explaining turnout variation in those countries where voting is not compulsory. Therefore, we sought an alternative variable, less restrictive than compulsory turnout, to capture the influence of national voting regulations and participation habits. Arguably, the best candidate for this task is turnout in the last national election preceding 
the EP election. This captures at least some of the second-order effects influencing turnout in EP elections, such as national registration variation, weekend voting, and habitual voting as well as compulsory voting. When this variable is included in a model with Franklin's three, it is significant and increases the model's explanatory power from an adjusted $\mathrm{R}^{2}$ of .756 to .783 . We then developed a series of regression models employing the last national election variable in concert with the economic and political variables described above (data not shown). Because the first vote variable was no longer significant in the presence of the last national election variable; it was dropped. Next, we tested the potency of our other variables, as we had done with Franklin's model. As before, neither the GDP in trade nor the net beneficiary variables were significant. The "original six" variable was no longer significant. But percentage of agricultural workers (.08 increase in variance explained) and EU host (.07) became significant. When we added these two indicators to those of last national election and election cycle, and regressed them on EP turnout for all five elections, all four variables achieved significance, with an adjusted $\mathrm{R}^{2}$ of .789 . See Table 3. Since two of the four EU institutional host countries have compulsory voting, this may be distorting our results despite the presence of the last national election factor as a control. Nevertheless, our revised model points to the need to look to a combination of national and EU influences to explain turnout in EP elections. 
TABLE 3

TWO MODELS: MULTIPLE REGRESSION OF EP TURNOUT WITH SELECTED EU AND NATIONAL INFLUENCE
INDICATORS (1979-1999 POOLED DATA)

\begin{tabular}{|c|c|c|}
\hline & Franklin Model & Alternative Mode \\
\hline Variables & $b($ s.e. $b)$ & $b($ s.e. $b)$ \\
\hline (Constant) & $54.081 * * *$ & $\begin{array}{l}-66.507^{* * *} \\
(12.095)\end{array}$ \\
\hline First Vote & $\begin{array}{c}8.554^{*} \\
(2.811)\end{array}$ & \\
\hline Compulsory Voting & $\begin{array}{l}32.254 * * * \\
(2.692)\end{array}$ & \\
\hline Election Cycle & $\begin{array}{l}-.273^{* *} \\
(.087)\end{array}$ & $\begin{array}{l}-.234^{* *} \\
(.082)\end{array}$ \\
\hline \multicolumn{2}{|l|}{ Turnout in last national election } & $\begin{array}{l}1.444 * * * \\
(.141)\end{array}$ \\
\hline \multicolumn{2}{|l|}{ EU institution host } & $\begin{array}{l}19.906^{* * *} \\
(2.875)\end{array}$ \\
\hline \multicolumn{2}{|l|}{ Agricultural workers (\%) } & $\begin{array}{l}1.272 * * * \\
(.177)\end{array}$ \\
\hline Adjusted $\mathrm{R}^{2}$ & .756 & .789 \\
\hline S.E.E. & 9.51 & 8.84 \\
\hline F statistic & $66.119 * * *$ & $60.003 * * *$ \\
\hline $\mathrm{N}=$ & 64 & 64 \\
\hline$=$ significant at .05 level $; * *=$ signifi & t.01 level; $* * *=$ si & 01 level. \\
\hline
\end{tabular}




\section{Comparing Model Performance Over Time}

Part of our critique of Franklin's model hinges on its future viability. One way to explore this is to compare the performance of his model for earlier and more recent EU elections. Thus we ran regressions based on pooled results for the two earliest elections, 1979 and 1984, and compared them with results for the most recent ones, 1994 and $1999 .{ }^{6}$ See Table 4. Both models perform well. However, our alternative model is superior in both time periods. With the exception of the electoral cycle in the first period, all of our variables are significant for both periods while only compulsory voting is significant in Franklin's model. This difference is even greater when Franklin's model is utilized without treating Italy as a case of compulsory voting in the 1994-1999 period (which he does). ${ }^{7}$ Then the $\mathrm{R}^{2}$ declines to .597 . Compared to the earlier period, the $\mathrm{R}^{2}$ in our model also declines for the most recent period, but all of its predictors are significant. $^{8}$ 
TABLE 4

\section{COMPARISON OF FRANKLIN AND ALTERNATIVE MODELS} FOR 1979-84 AND 1994-99

\begin{tabular}{|c|c|c|c|c|}
\hline Model & $\begin{array}{l}\text { Franklin } \\
1979-84\end{array}$ & $\begin{array}{l}\text { Alternative } \\
1979-84\end{array}$ & $\begin{array}{l}\text { Franklin } \\
1994-99\end{array}$ & $\begin{array}{l}\text { Alternative } \\
\text { 1994-99 }\end{array}$ \\
\hline \multicolumn{5}{|l|}{ Variables } \\
\hline (Constant) & $\begin{array}{l}60.152 \\
(5.749)^{* * * *}\end{array}$ & $\begin{array}{l}-95.187 \\
(19.933)^{* * *}\end{array}$ & $\begin{array}{l}51.388 \\
(3.923)^{* * *}\end{array}$ & $\begin{array}{l}-75.080 \\
(19.914)^{* * *}\end{array}$ \\
\hline First Vote & $\begin{array}{c}4.160 \\
(4.170)\end{array}$ & & $\begin{array}{l}14.429 \\
(6.345)\end{array}$ & \\
\hline Comp Vote & $\begin{array}{l}28.004 \\
(4.483)^{* * *}\end{array}$ & & $\begin{array}{l}33.791 \\
(4.459) * * *\end{array}$ & \\
\hline Eleccycle & $\begin{array}{l}-.316 \\
(.162)\end{array}$ & $\begin{array}{c}.0184 \\
(.125)\end{array}$ & $\begin{array}{l}-.302 \\
(.141)\end{array}$ & $\begin{array}{l}-.365 \\
(.128)^{* *}\end{array}$ \\
\hline Last National & & $\begin{array}{l}1.661 \\
(.208) * * *\end{array}$ & & $\begin{array}{l}1.561 \\
(.241)^{* * *}\end{array}$ \\
\hline EU Host & & $\begin{array}{l}25.184 \\
(3.791)^{* * *}\end{array}$ & & $\begin{array}{l}16.639 \\
\quad(4.892)^{* *}\end{array}$ \\
\hline Agworker & & $\begin{array}{l}1.410 \\
.206)^{* * *}\end{array}$ & & $\begin{array}{l}1.833 \\
(.392)^{* * *}\end{array}$ \\
\hline Adjusted $\mathrm{R}^{2}$ & .734 & .869 & .736 & .754 \\
\hline S.E.E. & 9.38 & 6.59 & 9.91 & 9.56 \\
\hline F Statistic & $20.357 * * *$ & $35.885 * * *$ & $27.923 * * *$ & $23.235 * * *$ \\
\hline $\mathrm{N}=$ & 22 & 22 & 30 & 30 \\
\hline
\end{tabular}

See Appendix for data sources. 
New variables available for the 1994 and 1999 elections permit the development of a further alternative testing for the influence of EU factors in explaining turnout variation. These are a more refined measure of the EU budget status of each member state, a revised Eurobarometer question tapping people's sense of European identity (see Frognier, 2002), and whether or not a country had adopted the euro as its currency (for 1999 only). We tested the impact of each of these by adding them individually to the model reported in Table 4. Neither the new budget measure nor euro membership provided significant additions to our model. However, the European identity measure did. When this five variable model was tested with the data for 1994 and 1999 combined, all the variables were significant and the model's adjusted $\mathrm{R}^{2}$ was .864. ${ }^{9}$ See Table 5. 
TABLE 5

MULTIPLE REGRESSION OF EP TURNOUT WITH SELECTED EU AND NATIONAL INFLUENCE INDICATORS (1994 AND 1999 POOLED DATA)

Variables

(Constant)

Turnout in last national election

Election cycle

EU institution host

Agricultural workers (\%)

European Identity

Adjusted $\mathrm{R}^{2}$

S.E.E.

F Statistic b

$-100.430 * * *$

$1.638 * * *$

$-.348 * *$

$12.825 * *$

$1.681 * * *$

$.361^{*}$

.864

7.3774

$34.132 * * *$

$\mathrm{N}=27$ s.e.b.

17.536

.201

.105

4.174

.309

.165

*Significant at the .05 level; **Significant at the .01 level; ***Significant at the .001 level. 
Although our model includes more variables than Franklin's, it performs substantially better for the two most recent EP elections. It also offers another explanation of why turnout in EP elections continues to decline. One factor is the decline of the agricultural workforce as a proportion of the total workforce (from $10.6 \%$ in 1979 to $6.5 \%$ in 1999). Second is the uncertain growth of European identity; it actually declined slightly between 1994 and 1999, in tandem with the spread of Euroscepticism (Taggart and Szczerbiak, 2001; McAllister and Studlar, 2000). Since our model shows that when a higher proportion of a country's population is engaged in agriculture or are European identifiers turnout will be higher, the decline of the first and the stagnation of the second do not bode well for turnout. Even more important is the historic trend of our last national election variable. The mean value for it has declined steadily since 1979, from 84.4 percent to 76.6 percent for 1999 . This is not due simply to the declining portion of EU members with compulsory voting, but to a reduction in turnout for national elections. There is a modest but measurable general decline in the salience of elections, whether national or EP (Flickinger and Studlar, 1992; Franklin et al., 2001). Countries hosting major EU institutions are similar to compulsory voting countries in that they have declined as a proportion of EU members. Thus the turnout boost associated with this effect is limited to fewer countries. ${ }^{10}$

\section{Conclusion}

Our alternative model attests to the presence of EU-related influences in the explanation of turnout in EP elections. Moreover, these influences--hosting a European institution, European identity, and the presence of agricultural workers-are theoretically meaningful. The last national election and electoral cycle variables indicate that domestic factors continue to be important for explaining EP turnout. The British case offers an illustration of both. In both 1994 and 1999 Britain was below the European mean for turnout in the last national election $(77.8 \%$ vs. $79 \%$ in 1994, $71.5 \%$ vs. $76.6 \%$ in 1999). Its electoral cycle also was longer than the European mean in both elections and therefore also acted to reduce turnout. But Britain is also below the European mean for size of the agricultural workforce (1.9\% vs. 6.5\%) and for European identity (38\% vs. $55.6 \%$ ). In terms of our model, this helps explain why British turnout was well below the 


\section{European mean.}

It is no longer justifiable to treat European elections as simply second order. True, no government is being selected through this process, and "rational" voters may find fewer reasons to take part. But European considerations are now among those reasons. As others have suggested (Evans, 1999: Curtice and Steed, 2000), we may be witnessing the "creeping Europeanization" of elections. 


\section{Notes}

1. We have attempted to replicate Franklin's model, but there are slight differences between our sources in reported turnout, and our election cycle measure is in months whereas Franklin's is in years with decimal fractions for partial years. Our election cycle data also differ from his in that we have actual data for the national elections coming after the 1999 EP election. He had to estimate it. Franklin also treats Italy as a compulsory voting country for all five elections, despite the fact that as of 1994 Italy no longer has compulsory voting (see Gray and Caul, 2000). However, in our replications we have treated Italy as Franklin does whenever the compulsory voting variable is used.

2. Our assumption is that citizens of countries which are major beneficiaries of the EU budget, have a substantial share of their economies in international trade, have a large agricultural work force, and are subscribers to the euro will be more sensitive to how the EU affects their lives.

3. This may be true from a costs as well as a benefits perspective, e.g., citizens of large contributor countries may also have this fact as an incentive to turn out. However, we do not test this hypothesis here.

4. Gray and Caul (2000) argue that extreme multi-partyism in national elections diminishes the voter's role in choosing a government and therefore discourages turnout. Franklin (2001a: 211) finds that over a quarter of voters choose different parties in EU elections than in national ones. He argues that this is because their EU votes are unconstrained by tactical consideration of who will form the government. But it can also be argued that citizens may be choosing parties at least partially on the basis of EU issues. Of course, EP elections are not about choosing a government.

5. EU salience, even if perceived, does not equal EP salience. Some indicators may be salient for sub-groups of the population and could affect their turnout levels, but investigating this is beyond the scope of this article.

6. The election of 1989 was omitted to enable comparison of the earliest and latest elections. 
7. Franklin (2001b) argues that habits formed by compulsory voting are likely to linger even after it is abolished. But even under compulsory voting turnout in Italy for both EP and national elections was never as high as in Belgium or Luxembourg.

8. Of course we must be wary of instability introduced by a diminished number of cases.

9. We are aware that this may be inflated by the small number of cases.

10. The electoral cycle variable can have different effects for each election, but its impact is bounded by the maximum time that may elapse between elections in each member state. Thus it is unlikely to be useful for explaining trends over several elections. 


\section{REFERENCES}

Anderson, Christopher (1998) 'Parties, Party Systems and Satisfaction with Democratic Performance in the New Europe', Political Studies 46: 572-88.

Begg, Iain and Nigel Grimwade (1998) Paying For Europe, Sheffield, UK: Sheffield Academic Press.

Blondel, Jean, Richard Sinnott and Palle Svensson (1998) People and Parliament in the European Union, Oxford: Clarendon Press.

Butler, David and Martine Westlake (eds) British Politics and European Elections 1999, New York: St. Martin's Press.

Cautrès, Bruno and Richard Sinnott (2002) 'The 1999 European Parliament Election and the Political Culture of European Integration', in Pascal Perrineau, Gérard Grunberg, and Colette Ysmal (eds) Europe at the Polls: The European Elections of 1999, pp.3-21, New York: Palgrave.

Crepaz, Markus M. L. (1990) 'The Impact of Party Polarization and Post-Materialism on Voter Turnout: A Comparative Study of 16 Industrial Democracies', European Journal of Political Research 18: 183-205.

Curtice, John. and Michael Steed (2000) 'Appendix: An Analysis of the Results', in David Butler and Martine Westlake (eds) British Politics and European Elections 1999, pp.240-56, New York: St. Martin's Press.

Delwit, Pascal (2002) 'Electoral Participation and the European Poll: A Limited Legitimacy' in Pascal Perrineau, Gérard Grunberg, and Colette Ysmal (eds) Europe at the Polls: The European Elections of 1999, pp.207-22, New York: Palgrave.

de Swaan, Abram (2002) 'The European Void: The Democratic Deficit as a Cultural Lack', European Studies Newsletter 31, Nos. 5/6 (June): 11-12.

Evans, Geoffrey (1999) ‘Europe: A New Electoral Cleavage?', in Geoffrey Evans and Pippa Norris (eds) Critical Elections: British Parties and Voters in Long-Term Perspective, pp.207-22, London: Sage.

Flickinger, Richard S. and Donley T. Studlar (1992) 'The Disappearing Voters? Exploring Declining Turnout in Western European Elections', West European Politics 15 (2): 1-16.

Franklin, Mark N. (2002) 'The Dynamics of Electoral Participation', in Lawrence LeDuc, Richard G. Niemi and Pippa Norris (eds) Comparing Democracies 2: New Challenges in the Study of Elections and Voting, pp. 148-68, Thousand Oaks, CA: Sage..

Franklin, Mark N. (2001a) 'European Elections and the European Voter', in Jeremy Richardson (ed) European Union: Power and Policy-making, pp.201-16, 2nd ed, 
London: Routledge.

Franklin, Mark N. (2001b) 'How Structural Factors Cause Turnout Variations at European Parliament Elections', European Union Politics 2: 309-28.

Franklin, Mark N. (1999) 'Electoral Engineering and Cross-National Turnout Differences: What Role for Compulsory Voting?', British Journal of Political Science 29: 205-24.

Franklin, Mark N. (1996) 'Electoral Participation', in Lawrence LeDuc, Richard G. Niemi and Pippa Norris (eds) Comparing Democracies: Elections and Voting in Global Perspective, pp. 216-35, Thousand Oaks, CA: Sage.

Franklin, Mark, Patrick Lyons and Michael Marsh (2001) 'The Tally of Turnout: How The Changing Character of Elections Drives Voter Turnout Variations in Established Democracies', Paper at Congress of European Consortium for Political Research, Canterbury, England.

Frognier, Andre-Paul (2002) 'Identity and Electoral Participation: For a European Approach to European Elections', in Pascal Perrineau, Gérard Grunberg, and Colette Ysmal (eds) Europe at the Polls: The European Elections of 1999, pp.4358, New York: Palgrave.

Gabel, Matthew (2000) 'European Integration, Voters and National Politics', West European Politics 23 (4): 52-72.

Gray, Mark and Miki Caul (2000) 'Declining Voter Turnout in Advanced Industrial Democracies, 1950-1997: The Effects of Declining Group Mobilization', Comparative Political Studies 33: 1091-1122.

Heath, Anthony, Iain McLean, Bridget Taylor, and John Curtice (1999) 'Between First and Second Order: A Comparison of Voting Behaviour in European and Local Elections in Britain', European Journal of Political Research 35:389-414.

Hix, Simon (2002) 'Constitutional Agenda-Setting Through Discretion in Rule Interpretation: Why the European Parliament Won at Amsterdam', British Journal of Political Science 32: 259-80.

Institute for Democracy and Electoral Assistance (2002) [voter turnout section of website] http://www.idea.int/vt/intro/introduction.cfm.

Lord, Christopher (2002) 'The New European Parliament' in Pascal Perrineau, Gérard Grunberg, and Colette Ysmal (eds) Europe at the Polls: The European Elections of 1999, pp.223-38, New York: Palgrave.

McAllister, Ian and Donley T. Studlar (2000) 'Conservative Euroscepticism and the Referendum Party in the 1997 British General Election', Party Politics 6: 359-71.

Marsh, Michael (1998) 'Testing the Second Order Elections Model after Four European Elections', British Journal of Political Science 28: 591-607. 
Melich, Anna. (2002) Eurobarometer 52.0: European Parliament Elections, the Single European Currency, and Financial Services, October-November 1999 [Computer file]. 2nd ICPSR version. Brussels, Belgium: INRA (Europe) [producer],1999. Cologne, Germany: Zentralarchiv fur Empirische Sozialforschung/Ann Arbor, MI: Inter-university Consortium for Political and Social Research [distributors].

Perrineau, Pascal, Gérard Grunberg, and Colette Ysmal (eds) (2002) Europe at the Polls: The European Elections of 1999, New York: Palgrave

Powell, G. Bingham, Jr. (1982) Contemporary Democracies: Participation, Stability, and Violence, Cambridge, MA: Harvard University Press.

Reif, Karlheinz (1997). 'European Elections as Member State Second-Order Elections Revisited', European Journal of Political Research 31: 17-43

Reif, Karlheinz and Hermann Schmitt (1980) 'Nine Second-Order National Elections: A Conceptual Framework for the Analysis of European Election Results', European Journal of Political Research 8: 3-44.

Schmitt, Hermann and Renato Mannheimer. 1991. 'About Voting and Non-Voting in the European Elections of June 1989', European Journal of Political Research 19: 31-54.

Schmitt, Hermann and Jacques Thomassen (2002) 'Dynamic Representation: The Case of European Integration', in Pascal Perrineau, Gérald Grunberg, and Colette Ysmal (eds) Europe at the Polls: The European Elections of 1999, pp.22-42, New York: Palgrave.

Smith, Julie (1999) Europe's Elected Parliament, Sheffield, UK: Sheffield Academic Press.

Taggart. Paul and Aleks Szczerbiak (2001) 'Crossing Europe: Patterns of Contemporary Party-Based Euroscepticism in EU Member States and the Candidate States of Central and Eastern Europe', Paper presented at American Political Science Association, San Francisco, CA.

van der Eijk, Cees, and Mark Franklin (1996) Choosing Europe? The European Electorate and National Politics in the Face of Union, Ann Arbor: University of Michigan Press. 


\section{APPENDIX}

\section{DESCRIPTION AND SOURCES OF VARIABLES IN THE ANALYSES}

Turnout. The percent of registered voters who voted. Smith (1999) for 1979-1994 and the European Parliament http://www2.europarl.eu.int/election/newep/en/tctp.htm for 1999.

Compulsory Vote. The compulsory voting countries are Belgium, Greece and Luxembourg. Italy was classified as compulsory for 1979 - 1989, but not for the past two elections. Italy formally abandoned compulsory voting in 1994 although enforcement of the provisions were always loose (Gray and Caul, 2000; Franklin, 2001b).

Last National. Turnout in the most recent national election, whether parliamentary or presidential (in those cases where presidents are directly elected).

EU Host. Belgium, Luxembourg and France are the countries for the Commission, Court, and Parliament, respectively. Germany became Central Bank host before the 1999 election.

Member Long. Calculated as the time from a country's initial year of membership to the election year.

Original Member. Belgium, Netherlands, Luxembourg, France, Germany, Italy.

GDP trade. Exports as a percentage of the country's GDP. Calculated from The OECD in Figures.

Agricultural Workers. Share of the country's workforce employed in agriculture. The OECD in Figures.

Net Beneficiary. Whether a country gains more from the EU budget than it contributes. Begg and Grimwade (1998).

Budget Contribution. Operational budgetary balance for each member state as \% of GDP (1994 \& 1999 only). Source: <http://europa.eu.int/comm/budget/agenda2000/reports_en.htm>.

Euro Member. Whether or not a country has adopted the Euro (1999 only).

EU Good. Is European unification a good thing or a bad thing? Calculated from the Eurobarometer cumulative file, Eurobarometers 41, 49 and 51.

Euro ID. Calculated from Eurobarometers 40 (1993) and 50 (1998).

EU Benefits Country. Does your country benefit from being a member of the EU? Calculated from the Eurobarometer cumulative file, Eurobarometers 41, 49 and 51.

Election Cycle. Time in months from the date of the EP election to the next national election. Calculated from data in Institute for Democracy and Electoral Assistance (1998) and Facts on File. 
$\mathbf{N}$ of parties. The number of political parties in a country winning at least one seat in the European Parliament election of the year. Smith (1999). 